\title{
VEGETATION IN THE HOME GARDENS "PEKARANGAN" IN WEST JAVA, INDONESIA
}

\author{
The Graduate School of Natural Science and Technology, Okayama University ARIFIN, Hadi S u silo \\ 1-1-1 Tsushima-naka, Okayama 700, Japan \\ Faculty of Agriculture, Okayama University SAKAMOTO, Keiji, CHIBA, Kyozo \\ 1-1-1 Tsushima-naka, Okayama 700, Japan
}

\section{INTRODUCTION}

Home gardens, "pekarangan" are defined to be open spaces surrounding privately owned houses in Indonesia. These gardens have a definite boundary which distinguishes them from other land and other home gardens. It is well known that these gardens have the function of agroforestry. They usually contain a mixture of perennial and annual crops, and domestic animals, which serve a variety of biophysical, economic and socio-cultural functions for the owner (Abdoellah, 1985; Soemarwoto and Christanty, 1985). Interaction among humans, plants and domestic animals is thought to maintain a specific ecosystem and the sustainable land use in a typical home garden.

Due to the rapid sprawl of the cities especially in West Java, the structure of home gardens is thoing.t to be changing remarkably. Agro-forestry functions and diversity of home gardens' elements are thought to be disappearing gradually. A study of the conservation planning of Indonesian home gardens is very important. The objective of the present study is to examine the effects of urbanization on vegetation in the home gardens of West Java, Indonesia.

\section{METHOD}

A survey of 115 home gardens in six study sites $(\mathrm{CB}=$ Cibakung, $\mathrm{SP}=$ Sirnagalih $\mathrm{Pagentongan}, \mathrm{BS}=\mathrm{Bab}$ akan Sukaningal, TO=Tegal Gundil Old Settlement, $\mathrm{TN}=$ Tegal Gundil New Settlement, BI=Baranangsiang Indah) was conducted in the Cianjur District, Bogor District and Bogor Municipality in West Java Province, Indonesia (Fig. 1) from July to August, 1995. Random sampling was taken in neighborhood units (Rukun Tetangga) or cluster units (Rukun Warga) in the study sites. Vegetation in the home gardens was identified by the inventory of species and their locations, counting the number of individual species, and measuring the height of the plants. Householders were interviewed in order to get information about the functions of the vegetation in the home gardens. Geographical, social, and economical information was collected. by interviewing the householders. The secondary data was gathered from reports and maps.

Geographical, social, economical, and vegetation data of six study sites were analyzed. The combination of that data resulted in vegetation performances in the home gardens in various intensities of urbanization.

\section{RESULTS AND DISCUSSION}

According to the principle component analysis with geographical, social and economical variables, the study sites could be ordered into less urbanized (CB), intermediately urbanized (SP, BS and TO) and the most urbanized (TN and BI) characters (Fig. 2). Comparisons of the vegetation in the home gardens were concerned with urbanization.

Species in the home gardens were grouped depending on the urbanization level by cluster analysis. There are 43 species which had a frequency more than $50 \%$ in the study sites (Table 1). Acalypha siamensis Olever (an ornamental plant for hedging), Leucaena glauca Bth., Capsicum frustescens L. and Parkisa speciosa Hassk. (vegetable

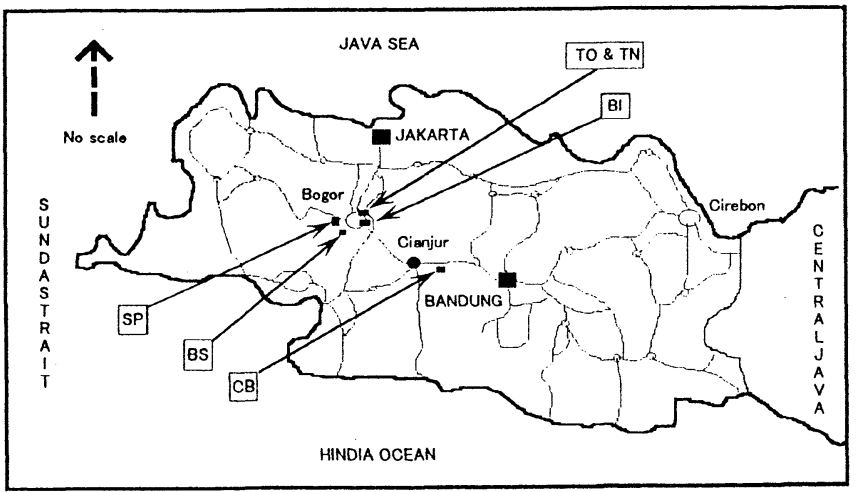

Fig. 1. Location of the study sites, West Java, Indonesia. 


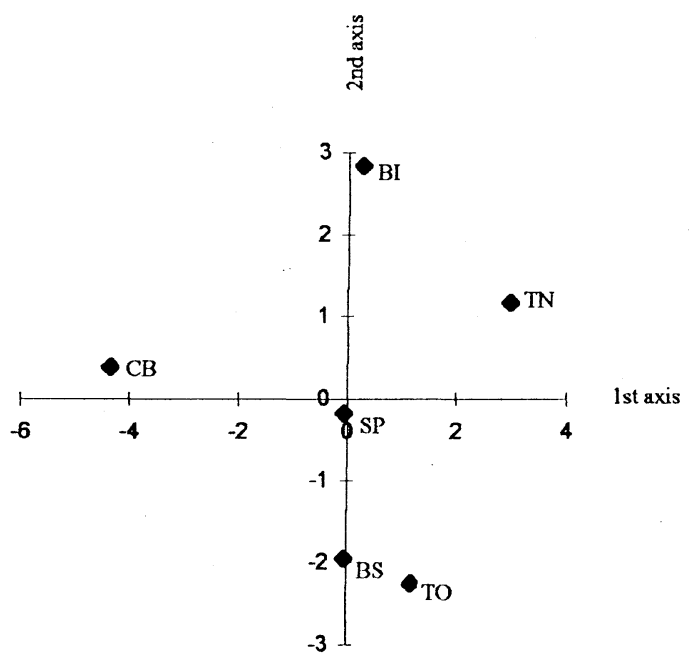

Fig. 2. Scatter diagraam of the study sites by PCA..

crops), and Annona muricata L. (fruit plant) occurred frequently in less urbanized home gardens. Eight species of fruit plants, one species of starchy crop (Manihot esculenta Crantz.) and one species of ornamental plant (Cordyline fruticosa A. Chev) occurred frequently in both less and intermediately urbanized home gardens. Aglonema simplex BL. and Impatiens balsamina $\mathrm{L}$. were predominant in intermediately urbanized home gardens. There were 13 species of ornamental plants, such as Ixora hybrida, Axonopus compressus P.B. and Zoysia matrella Merr. (lawn grasses), Portulaca oleracea L., Rosa hybrida Hort., Rhapis exelsa (thunb) Henry ex., Bougenvillea spectabilis Willd., etc. were frequently found in the most urbanized home gardens. Seven species of ornamental plants, 2 species of fruit plants, 1 species of vegetable and spice crop respectively were very common in all levels of urbanization. TO had no specific species because almost all of the species had low frequencies.

Plants in the home garden were divided into ornamental plants species and non-ornamental plants species. Non ornamental plant species were found to be predominant in less and intermediately urbanized home gardens. Conversely, ornamental plant species were predominant in the most urbanized home gardens. The ratio of ornamental and non ornamental species was 4:6 in CB. On the other hand the ratio was 7:3 in both of $\mathrm{TN}$ and $\mathrm{BI}$. However, the ratio were $4: 6,5: 5$ and $6: 4$ in BS, SP and TO respectively. Most of the plants were grown for aesthetic purposes in the most urbanized home gardens, but the ratio of plants for production purposes was higher in intermediately and less urbanized home gardens. Those results are supported by Abdoellah (1985) which stated that the number of
Table 1. Group of vegetation based on the cluster analysis.

\begin{tabular}{|c|c|c|c|c|c|c|}
\hline $\begin{array}{r}\text { Latin name } \\
\end{array}$ & $\mathrm{CB}$ & $\mathrm{SP}$ & $\overline{B S}$ & TO & $\mathrm{TN}$ & BI \\
\hline Acalypha siamensis Olever & (1) & 2 & 1 & 1 & 1 & 1 \\
\hline Leucaena glauca Bth. & $1-$ & 1 & 1 & 1 & 1 & 1 \\
\hline C'apsicum frustescens $L$. & 1 & 1 & 1 & 1 & 1 & 1 \\
\hline Parkisa speciosa Hassk. & 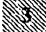 & 1 & 1 & 1 & 1 & 1 \\
\hline Annona muricata $L$ & (1) & 1 & 1 & 1 & 1 & 1 \\
\hline Aglaonema simplex BL. & 1 & 1 & (1) & 1 & 2 & 1 \\
\hline Dendrobium phalaenopsis Fitzq & 1 & 1. & w & 1 & 1 & l \\
\hline Impatiens balsamina $L$ & 1 & 1 & L & 1 & 1 & 1 \\
\hline Xanthosomasp. & 1 & & iv & 1 & 1 & 1 \\
\hline Txorahybrid & J & 1 & 1 & 1 & & S \\
\hline Axonopus compressus P.B. & 1 & 2 & 1 & 1 & 1. & 1. \\
\hline Loysia matrella Merr. & 1 & 1 & 1 & 1 & 1 & 1 \\
\hline Portulaca oleracea $L$ & 1 & 1 & 1 & 1 & w. & 3. \\
\hline C'hrysalidicarfius intescens & 1 & 1 & 1 & 1 & 1. & 1 \\
\hline Rosa hybrida Hort & 1 & 2 & 2 & 1 & 1. & N \\
\hline Rhapis exelsa (Ihunb)Henry ex. Rehder & 1 & 2 & 1 & 1 & . & 1. \\
\hline Pleomelle elliptica (Rhumb) & 3 & 2 & 1 & 1 & * & - \\
\hline Bougemvillea spectabilis Willd. & 3 & 2 & 1 & 1 & . & 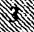 \\
\hline l'orfulaca grandiflora Lindl. & 1 & 1 & 1 & 1 & ( & - \\
\hline Cuphea sp. & 2 & 1 & 2 & 1 & - & 1. \\
\hline Hilicium desipiens $7 \mathrm{hw}$. & 1 & 1 & 1 & 1 & 1. & 1 \\
\hline Cyrtostachys lakka Becc. & 1 & 1 & 1 & 1 & st & H \\
\hline Psidium guajava L. & 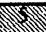 & W. & 4 & $\overline{2}$ & i & 2 \\
\hline Nephelium lappaceum $L$. & 1 & (1) & - & 1 & 2 & 2 \\
\hline Carica papaja $L$. & (1) & 1 & 1 & 2 & 3 & 2 \\
\hline Artocarpus integra Merr. & - & $\ldots$ & - & 1 & 1 & 1 \\
\hline Colocasia esculenta (L.) Schott & - & 1. & 2. & 1 & 1 & 1 \\
\hline Mangifera indica $L$. & (5) & - & - & 2 & 2 & 2 \\
\hline Musa paradisiaca $L$. & 18 & 1. & 1. & 2 & 1 & 1 \\
\hline Cocos mucifera 1 & - & - & L & 1 & 1 & 1 \\
\hline Manihot esculenta Crantz. & - & 1 & * & 2 & 1 & 2 \\
\hline Cordyline fruticos $a$ A. C'hev & IN & (1) & - & 2 & 1 & 2 \\
\hline Duranta erecta $L$ & 1 & 1. & \% & N & 4 & (1) \\
\hline Nephrolepis exaltata sichott & . & (1) & N & 1 & (1. & 1 \\
\hline Dieffenbachia foumieri Hort & \& & 1. & 1 & 1. & 1 & - \\
\hline Capsicum annum $L$. & . & 1. & 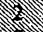 & 1 & - & ? \\
\hline Adiantum cuneatum $L$ & . & 4 & - & t. & ( & 1. \\
\hline Pandamus amaryllifolous Roxb & 1 & L. & - & - & . & (1. \\
\hline Syzygium aqueum Burm.f. & W & 1. & 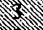 & . & - & L \\
\hline Dracaena fragrams N.E.Br. & . & 1. & - & 1 & 2 & 1. \\
\hline C'itrus sinensis Usb. & 1. & (1) & 1 & - & W & (1) \\
\hline Caladium bicolor (W.Ait) Vent & - & - & 1. & 1 & 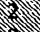 & 18 \\
\hline Anthurium cristalium & 4 & i. & (2) & - & 1 & in \\
\hline
\end{tabular}

Weighting of freq.: $l=0-20 \% ; 2=21-40 \% ; 3=41-60 \% ; 4=61-80 \% ; 5=81-100 \%$
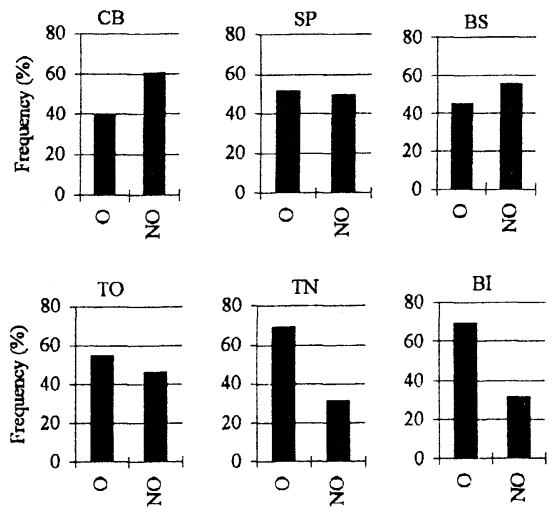

Plant classes

Fig. 3. Classification of plants in each study site ( $O=$ ornamental plant; $N O=$ non ornamental plant).

individuals and species of ornamental plants in homegardens varies with distance to the city. The higher the urbanization level, the higher the number of ornamental plants species. 

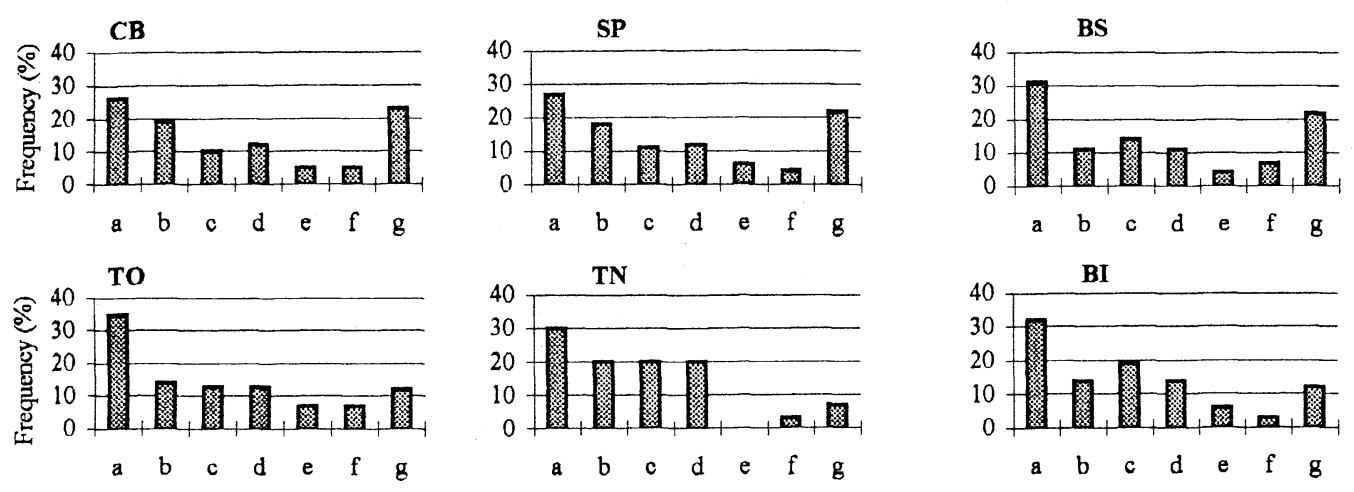

a: fruit; b: vegetable; c: spice; d: medicine; e: starchy; f: industry; g: miscellaneous.

Fig. 4. Frequency $(\%)$ of non ornamental plant species in each study site.

The spatial pattern of home gardens were zoned to the house building, i.e. the front, back and side yards. Fig. 3 shows the distribution of ornamental and non ornamental plants in the zones of home gardens in each study site. The ratio of non ornamental plants increased from front yard to back and side yards in all of 3 levels of urbanization areas. In the home gardens, plants were grown for aesthetic purposes in front yards as a welcome area, but plants for production were planted more often in the back and side yards.

According to the main function of plants in the home gardens, non ornamental plants species were classified into fruit plants, vegetable crops, spice plants, medicinal plants, starchy crops, industrial plants and miscellaneous (Karyono et al, 1977; Karyono et al, 1978; Kubota et al, 1992; Kubota et al, 1992). Fruit plants were more dominant than the others in all levels of urbanization of study sites (Fig. 4). In the most urbanized area, fruit plants also had aesthetic values especially in the fruiting time. Miscellaneous uses of plant such as fuel woods, shading trees, wood plants for handicraft or building construction, forage crops, plants for soil and water conservation, etc. were higher in intermediately and less urbanized areas than in the most urbanized area. It was thought that profession, especially farmers are supposed to have influenced the structure of home gardens. They used the product of plants for subsistence and commercial. Frequencies of vegetable, spice, medicine, starchy and industrial plants did not depend on the urbanization.

Positive correlation was detected between areas of the open space in home gardens and the number of species in each of the study sites ( $p<0.001$ ). The coefficient of correlation values from the lowest to the highest were 0.2133 (SP), 0.5493 (TO), 0.6089 (BI), 0.7025 (TN), $0.7277(\mathrm{CB})$ and 0.8515 (BS). The larger the open space, the greater the number of species which were found in the home gardens. Those tendencies did not depend on the urbanization level. Based on the observation, among the study sites the maximum number of species that were found in home gardens in SP was 270 . In contrast, we found only 154 species in the home gardens of BS. Therefore, the larger the open space in SP had no relation to the number of species. When the SP's house holders have larger home gardens, the number of individuals of species which have economic value increases, such as ornamental and fruit plants' nurseries.

\section{REFERENCES}

Abdoellah, Oekan Soekotjo. 1985. Home gardens in Java and their future development. The First International Workshop on Tropical Home Garden. Institute of Ecology Padjadjaran University, Bandung. pp. 28.

Karyono, et al. 1977. Laporan Sementara Penelitian Ekologi Pekarangan di Daerah Pedesaan DAS Citarum: Struktur Pekarangan. Seminar Terbatas Ekologi Pekarangan, lembaga Ekologi Universitas Padjadjaran, Bandung. pp. 161. (In Indonesian).

Karyono, et al. 1978. Struktur pekarangan di daerah aliran sungai Citarum Jawa Barat. Seminar Ekologi Pekarangan II, Lembaga Ekologi, Universitas Padjadjaran, Bandung. pp. 152. (In Indonesian).

Kubota, N., E. Yuda and Y. Yamamoto. 1992. Utilization of cultivated plants in home gardens with or without a fish pond in West Java. Japanese J. Trop. Agric. 36:127-134.

Kubota, N, T. Ogo and N. Utsunomiya 1992. Cultivation and utilization of useful plants in home gardens in Java Island. Japanese J. Trop. Agric. 36:99-110. (In Japanese with English Summary).

Soemarwoto, O. and L. Christanty. 1985. Home garden in the tropics. Home Garden Source Book, Vol. I Home Garden Issues and Ecological Aspect. The First International Workshop on Tropical Home Garden. Institute of Ecology Padjadjaran University Bandung, Indonesia. pp. 25.

(Presented at 6 th Annual Conference of (ALE-J) 